\title{
Peningkatan Hasil Belajar Matematika Siswa Menggunakan Strategi Pembelajaran MaKe A Match dan IndeX CaRd Match PADA SISWA KELAS VIII SMPN 1 KoTO XI TARUSAN TAHUN PELAJARAN 2016/2017
}

\author{
Enhancing Mathematical Students' Learning Result Using MaKe A Match \\ AND INDEX CARD MATCH LEARNING STRATEGIES IN STUDENTS CLASS VIII SMPN 1 \\ KOTO XI TARUSAN SCHOOL YEAR 2016/2017
}

\author{
Villia Anggraini' ${ }^{1}$, Lucky Heriyanti Jufri ${ }^{2}$ dan Wella Juliati ${ }^{3}$ \\ 1 Staff Pengajar Program Studi Pendidikan Matematika, STKIP PGRI SUMBAR \\ Padang, Sumatera Barat, Indonesia \\ villia@gmail.com \\ 2 Staff Pengajar Program Studi Pendidikan Matematika, STKIP PGRI SUMBAR \\ Padang, Sumatera Barat, Indonesia \\ 3 Mahasiswa Program Studi Pendidikan Matematika, STKIP PGRI SUMBAR \\ Padang, Sumatera Barat, Indonesia
}

\begin{abstract}
Abstrak
Penelitian ini dilatarbelakangi oleh rendahnya hasil belajar dan minat siswa untuk mengulang pelajaran yang telah dipelajarinya. Mengatasi masalah tersebut penulis melaksanakan pembelajaran dengan menerapkan strategi pembelajaran Make A Match dan Index Card Match. Penelitian ini bertujuan untuk mengetahui bagaimana peningkatan hasil belajar matematika siswa dengan menerapkan strategi pembelajaran Make A Match dan Index Card Match. Jenis penelitian ini adalah kuasi eksperimen, dengan rancangan penelitian Nonequivalent Control Group Design. Populasi dalam penelitian ini adalah seluruh siswa kelas VIII SMPN 1 Koto XI Tarusan dan yang terpilih sebagai kelas sampel adalah kelas VIII.2 dan kelas VIII.3. Instrumen yang digunakan dalam penelitian ini adalah pretest dan posttest. Bentuk tes yang digunakan adalah tes uraian. Hasil analisis butir soal diperoleh soal tes reliabel dengan reliabilitas tes adalah $r_{11}=0,8421$. Berdasarkan pengujian hipotesis menggunakan uji $t$ satu arah diperoleh $t_{\text {hitung }}=$ 3,17 dan $t_{\text {tabel }}=1,676$ karena $t_{\text {hitung }}>t_{\text {tabel }}$ maka $H_{0}$ ditolak dan $H_{1}$ diterima sehingga dapat disimpulkan bahwa peningkatan hasil belajar matematika siswa menerapkan strategi pembelajaran Make A Match lebih baik dari peningkatan hasil belajar matematika siswa menerapkan strategi pembelajaran Index Card Match pada siswa kelas VIII SMPN 1 Koto XI Tarusan Tahun Pelajaran 2016/2017.

Kata Kunci: Make A Match, Index Card Match, hasil belajar.
\end{abstract}

\section{Abstract}

The background of the research is caused by student learning outcomes and interest in learning to review the lesson that is still low. To solve these problems, the researcher doing learn by 
applying strategies for learning Make A Match and index Card Match. This research aims to know the improvement mathematics student learning outcomes by applying strategies for learning Make A Match and index Card Match. The types of this research is A quasi-experiment with Nonequivalent Control Group Design. The population of this research is whole students in class VIII SMPN 1 Koto XI Tarusan, the sample is class VIII.2 and class VIII.3. The instrument used is pretest and posttest. The test form that used is essay with reliability $r_{11}=0,8421$. base on the hypothesis test which applying test one side, it obtained $t_{\text {count }}=3,17$ and $t_{\text {table }}=1,676$ for $t_{\text {count }}>t_{\text {table }}$ then rejected $H_{0}$ and accepted $H_{1}$. Therefore, it can be concluded the improvement mathematics student learning outcomes by applying strategies for learning Make A Match better than improvement mathematics student learning outcomes by applying strategies for learning Index Card Match in class VIII SMPN 1 Koto XI Tarusan in school year 2016/2017.

Keyword: Make A Match, Index Card Match, learning outcomes.

\section{Pendahuluan}

Matematika bukanlah sekedar kumpulan angka, simbol, dan rumus yang tidak ada kaitannya dengan dunia nyata. Justru sebaliknya, matematika tumbuh dan berakar dari dunia nyata. Matematika melatih kita untuk menjadi manusia yang cermat, teliti dan tidak ceroboh dalam bertindak. Selain itu matematika juga mengajarkan kita untuk menjadi pribadi yang sabar dalam menghadapi segala permasalahan kehidupan. Matematika juga membantu kita dalam hal menghitung uang, laba, rugi dan berbagai permasalahan lain, bahkan hampir seluruh ilmu didunia ini menyentuh yang namanya matematika. Melihat begitu pentingnya ilmu matematika sudah selayaknya kemampuan matematika harus ditingkatkan, baik ditingkat SD, SMP maupun SMA.

Keberhasilan proses pembelajaran matematika dapat diukur dari keberhasilan siswa yang mengikuti kegiatan pembelajaran tersebut. Keberhasilan itu salah satunya dapat dilihat dari hasil belajar siswa. Hasil belajar adalah sesuatu yang diperoleh siswa setelah melakukan proses Pembelajaran dan menjadi tolak ukur untuk menentukan tingkat keberhasilan siswa dalam menguasai materi pelajaran. Guru sebagai orang yang terlibat langsung dalam proses pembelajaran diharapkan dapat menciptakan kondisi belajar yang kondusif, efektif dan efisien serta dapat memahami karakteristik siswa yang berbeda. Dengan demikian proses pembelajaran dapat meningkatkan hasil belajar matematika.

Berdasarkan observasi yang dilakukan di SMPN 1 Koto XI Tarusan tanggal 4-6 Februari 2016, ditemukan beberapa masalah dalam proses pembelajaran matematika. Interaksi aktif positif antara siswa dengan guru, atau siswa dengan siswa jarang terjadi. Siswa kurang terampil menjawab pertanyaan atau bertanya tentang materi yang diajarkan dan kurang bisa bekerja sama dalam kelompok. Mereka cenderung bekerja sendiri-sendiri bahkan banyak diantara mereka yang melakukan aktifitas lain di luar proses pembelajaran.

Siswa bersikap pasif sehingga keterlibatan mereka rendah, siswa lebih banyak menunggu sajian dari guru dari 
pada menemukan sendiri pengetahuan, keterampilan serta sikap yang mereka butuhkan. Selain itu siswa juga tidak mau mengulang pelajaran yang telah dipelajari sebelumnya. Sehingga menyebabkan hasil belajar siswa menjadi rendah.

Salah satu alternatif untuk menyelesaikan permasalahan di atas adalah dengan menerapkan strategi pembelajaran Index Card Match dan Make A Match. Index Card Match dan Make A Match adalah strategi pembelajaran yang mampu mengajak siswa belajar sambil bermain dengan menggunakan kartu, sehingga suasana kegembiraan akan tumbuh dalam pembelajaran.

Menurut Lorna Curran dalam Lie (2002:54) langkah-langkah penerapan pembelajaran kooperatif tipe Make $A$ Match (mencari pasangan) adalah guru menyiapkan beberapa kartu yang berisi beberapa konsep atau topik yang telah diajarkan. Setiap siswa mendapat satu buah kartu. Setiap siswa mencari pasangan yang mempunyai kartu yang cocok dengan kartunya dan duduk berkelompok.

Sedangkan

langkah-langkah pelaksanaan strategi pembelajaran aktif tipe Index Card Match yang di kemukakan oleh Silberman (2013 : 250-251) adalah Guru menyiapkan kartu sejumlah peserta didik yang ada dalam kelas. Tulis pertanyaan tentang materi yang telah di berikan sebelumnya pada setengah bagian kertas yang disiapkan. Setiap kertas berisi satu pertanyaan. Pada potongan kertas yang lain, tulis jawaban dari pertanyaanpertanyaan yang telah dibuat. Kocoklah semua kertas sehingga akan tercampur antara soal dan jawaban. Bagikan kepada setiap peserta didik satu potongan kertas. Sebagian peserta didik akan mendapatkan soal dan sebagian yang lain akan mendapatkan jawaban. Minta perserta didik untuk menemukan pasangan mereka. Jika ada yang sudah menemukan pasangan, minta mereka untuk duduk berdekatan. Setelah semua peserta didik menemukan pasangan dan duduk berdekatan, minta secara bergantian untuk membacakan soal yang di peroleh dengan keras kepada teman-teman yang lain. Selanjutnya soal tersebut di jawab oleh pasangan yang lain.

Tujuan diadakannya penelitian ini adalah untuk mengetahui apakah peningkatan hasil belajar matematika siswa yang mendapatkan pembelajaran dengan menggunakan Make A Match lebih baik dari pada siswa yang memperoleh pembelajaran dengan menggunakan Index Card Match.

Penelitian yang relevan dengan penelitian ini adalah penelitian yang telah dilakukan oleh Sriweni Armita (2015) dengan judul pengaruh Penerapan strategi pembelajaranan aktif tipe index card match terhadap pemahaman konsep matematiks siswa kelas VIII SMPN 2 Lengayang tahun pelajaran 2014/2015. Kesimpulan yang didapat bahwa pemahaman konsep matematis siswa dengan menggunakan strategi pembelajaran aktif tipe index card match mempengaruhi pemahaman konsep siswa kelas VIII SMPN 2 Lengayang. 
Vivi Afdarni (2016) dengan judul pengaruh penerapan model pembelajaran kooperatif disertai Make A Match terhadap pemahaman konsep matematis siswa kelas X SMAN 4 Sijunjung tahun pelajaran 2015/2016. Kesimpulan yang didapat bahwa pemahaman konsep matematis siswa dengan menerapkan model pembelajaran kooperatif disertai Make A Match lebih baik dari pada pemahan konsep matematis siswa dengan penerapan pembelajaran konvensional di kelas X SMAN 4 Sijunjung.

\section{Metode}

Jenis penelitian ini adalah penelitian kuasi eksperimen. Penelitian ini menggunakan rancangan yang dikemukakan oleh Sugiyono ( 2011: 116) yaitu desain kelompok kontrol nonekivalen (nonequivalent control grup design). Penelitian ini terdiri atas dua kelas eksperimen 1 dan eksperimen 2. Merujuk pada Arikunto (2010) variabel bebas dalam penelitian ini adalah strategi make a match dan index card match. Variabel terikat dalam penelitian ini adalah hasil belajar matematika siswa kelas VIII SMPN 1 Tarusan Tahun Pelajaran 2016/2017.

Populasi dalam penelitian ini adalah siswa kelas VIII SMPN 1 Tarusan Tahun Pelajaran 2016/2017. Teknik pengambilan sampel pada penelitian ini adalah secara acak. Kelas sampel yang terpilih adalah kelas VIII 3 sebagai kelas eksperimen 1 dan kelas VIII 2 sebagai kelas eksperimen 2. Instrumen yang digunakan pada penelitian ini adalah pretest dan postest. Sebelum dilaksanakan pretest dan postest dilakukan uji coba soal pada kelas IX 1 SMPN 9 Tarusan pada tanggal 28 juli 2016. Hasil uji coba tes menunjukkan ada satu soal yang dibuang. Reliabilitas soal adalah 0,841. Teknik analisis data yang dipakai adalah uji t satu pihak.

\section{Hasil dan Pembahasan}

Berdasarkan penelitian yang dilakukan pada kedua kelas sampel Pretest dan Posttest diperoleh dari data hasil belajar siswa pada tipe Make A Match dan Index Card Match. Peserta dari tes ini adalah 23 orang kelas eksperimen 1 dan 26 orang kelas eksperimen 2 .

Tabel 1.

Analisis Rata-rata Pretest, Postest dan N-Gain

\begin{tabular}{llll|}
\hline Kelas Sampel & Pretest & Postest & N-Gain \\
\hline Eks 1 & 13,77 & 68,92 & 0,62 \\
\hline Eks 2 & 22,15 & 56,27 & 0,45 \\
\hline
\end{tabular}

Pada Tabel 1 rata-rata pretest pada kelas eksperimen 1 adalah 13,77 dan ratarata pada kelas eksperimen 2 adalah 22,15 . Ini menunjukkan bahwa skor pretest pada kelas eksperimen 2 lebih baik dari pada skor pretest kelas eksperimen 1. Sedangkan rata-rata skor postest siswa kelas eksperimen 1 adalah 68,92 dan ratarata skor postest kelas eksperimen 2 adalah 56,27. Ini menunjukkan bahwa peningkatan nilai postest siswa pada kelas eksperimen 1 lebih baik dari pada kelas eksperimen 2. Dari kedua kelas sampel dapat dikatakan juga bahwa hasil postest yang diperoleh kelas eksperimen 1 dan eksperimen 2 lebih baik dari nilai pretest. 
Rata-rata skor N-Gain pada kelas eksperimen 1 adalah 0,64, sedangkan ratarata skor $\mathrm{N}$-Gain pada kelas eksperimen 2 adalah 0,45. Ini menunjukkan bahwa pada kelas eksperimen 1 terjadi peningkatan hasil belajar lebih dari 50\% sedangkan peningkatan hasil belajar kelas eksperimen 2 kurang dari 50\%.

Setelah dilakukan uji normalitas dan uji homogenitas diperoleh bahwa nilai tes hasil belajar siswa pada kedua kelas sampel berdistribusi normal dan homogen, maka uji hipotesis yang digunakan adalah uji t satu pihak. Dari perhitungan diperoleh nilai $t=3,17$. Sedangkan $t_{\text {tabel }}=1,676$. Karena nilai $t_{\text {hitung }}$ $>t_{\text {tabel }}$ maka tolak $\mathrm{H}_{0}$ atau terima $\mathrm{H}_{1}$.

Pada kelas eksperimen 1 strategi yang digunakan adalah Make A Match dan anggota kelompoknya lebih dari dua orang. Kelompok yang lebih dari dua orang akan mempengaruhi hasil kerja kelompok, karena semakin banyak kepala maka akan semakin banyak ide yang muncul. Pada make a match dalam 1 kelompok hanya ada 1 kartu rumus dan kartu soal lebih dari 1 sehingga siswa lebih banyak mengerjakan soal dan latihan. Sedangkan pada eksperimen 2 pembelajaran menggunakan strategi Index Card Match yang mana kelompoknya hanya terdiri atas 2 orang saja. Kelompok hanya mengerjakan satu soal saja, sehingga tidak banyak jenis soal yang dapat dibahas. Jadi dapat disimpulkan bahwa peningkatan hasil belajar siswa yang mendapatkan pembelajaran dengan menggunakan Make a Match lebih baik dari pada siswa yang memperoleh pembelajaran dengan menggunakan Index Card Match.

\section{Penutup}

Berdasarkan hasil penelitian yang diperoleh setelah melakukan analisis dan pembahasan terhadap masalah yang telah dikemukakan dalam penelitian ini, maka dapat disimpulkan peningkatan hasil belajar matematika siswa yang menggunakan strategi Make A match lebih baik dari peningkatan hasil belajar matematika siswa menggunakan strategi Index Card Match pada siswa kelas VIII SMPN 1 Koto XI Tarusan.

\section{DAFTAR Pustaka}

Arikunto, Suharsimi.2010. Prosedur Penelitian. Jakarta: Rineka Cipta.

Afdarni ,Vivi. 2016. Pengaruh penerapan model pembelajaran kooperatif disertai Make A Match terhadap pemahaman konsep matematis siswa kelas $X$ SMAN 4 Sijunjung tahun pelajaran 2015/2016. Padang :STKIP PGRI.

Armita, Sriweni. 2015. Pengaruh penerapan strategi pembelajaran aktif tipe Index Card Match iterhadap pemahaman konsep matematis siswa kelas VIII SMPN 2 Lengayang tahun pelajaran 2014/2015. Padang: STKIP PGRI

Hake, R. R. 1999. Analazing Change/ Gain Scores, (http//www. physics.indiana.edu/ sdi/ Analyzing change - Gain.pdf, diakses 25 maret 2016). 
Lie, Anita . 2002. Cooperative Learning: Mempraktekkan Cooperative di Ruang Kelas. Jakarta: Grasindo.

Silberman,melvin. 2013. Active Learning:101 cara belajar siswa aktif. Bandung : Nuansa Cendekia.
Sudjana. 2005. Metode Statistika. Bandung: Tarsito.

Sugiyono. (2011). Metode Penelitian Pendidikan. Bandung: Alfabeta. 